\title{
Mulheres Negras na Política: O futuro é uma mulher preta
}

\section{Mônica Francisco ${ }^{1}$}

Um fato, que não pode ser negado, é a sub-representação das mulheres negras nos espaços institucionais. Tudo foi construído para o homem branco, depois para a mulher branca. Depois, bem depois, está o homem negro. E lá longe, bem no fundo, a mulher negra. Na Assembleia Legislativa do Estado do Rio de Janeiro é assim: homens brancos, casados, com média de 46 anos e nível superior completo. Este é o perfil dos parlamentares que ocupam a maioria das 70 cadeiras da Alerj. As mulheres ocupam 12 das 70 cadeiras, representando 17,15\% dos deputados eleitos.

A situação se agrava quando fazemos o recorte por raça: somente quatro pretos eleitos. A maioria segue branca: 48 parlamentares se declaram brancos, 18 se declararam pardos. Dos negros eleitos, todas mulheres. É exatamente nessa interseção que me encontro. Eu, Mônica Francisco, cientista social formada pela Universidade do Estado Rio de Janeiro. Fui assessora de Marielle Franco e estou no meu primeiro mandato como deputada estadual pelo PSOL.

Na Câmara dos Deputados, em Brasília, dos 513 deputados eleitos na atual legislatura, 21 se declaram pretos, sendo 13 mulheres definidas como pretas ou pardas. Apesar do evidente crescimento, em relação as legislaturas anteriores - em 2010, eram três; no pleito de 2014, foram 12 eleitas - ainda é um crescimento modesto.

\footnotetext{
Submetido em: 02/12/2019 - Aceito em: 02/12/2019 - Publicado em: 28/12/2019.

${ }^{1}$ Mônica Francisco é uma mulher preta, favelada, evangélica progressista que sabe seu lugar de fala e o usa para fazer ecoar as vozes periféricas, feministas, LGBTQIs, e de todas e todos que vivem no Rio de Janeiro. Nascida no morro do Borel, na Zona Norte do Rio, Mônica Francisco é formada em Ciências Sociais, pela Universidade do Estado do Rio de Janeiro (Uerj), graças às cotas, é militante dos direitos humanos e foi eleita deputada estadual pelo Rio de Janeiro em 2018.
} 
A história revela que as mulheres negras são alijadas da vida pública, além de detentoras dos piores indicadores sociais do país, trabalhando mais e ganhando menos. Esse é um dos desafios para que mulheres negras entrem na vida pública. Com financiamento de campanha insuficiente, resultante da má distribuição dos recursos nos partidos políticos, as negras que seguem por esse caminho são obrigadas a contar com ações e fundos de grupos de fortalecimento de mulheres nos processos eleitorais. Um estudo da Fundação Cidadania Inteligente indicou que, em 2014 - na eleição anterior à atual - somente 2,51\% das despesas com candidatos ao Legislativo foram destinadas às negras.

A rede de apoio tem sido fundamental nesse crescimento modesto. Há, sem dúvidas, um efeito causado pelo assassinato de Marielle Franco. No rastro da morte trágica da vereadora, 521 mulheres negras se lançaram candidatas no estado do Rio, um aumento de 52\% na comparação com 2014. As mulheres negras estão se organizando, até mais que os homens negros. Esse é um passo para as mudanças que estão se desenhando: a mulher negra vai chegar ao lugar que ela quiser. É questão de tempo.

Se a distribuição desequilibrada de recursos nas campanhas e nos partidos é um dos elementos responsáveis pela sub-representação das mulheres negras na política, tornando o processo lento, o outro elemento é o racismo.

"Quando a mulher negra se movimenta, toda a estrutura da sociedade se movimenta com ela" (Angela Davis). O racismo estrutural brasileiro é responsável pelo baixo índice de negros e negras nos espaços de visibilidade positiva, prestígio e poder no Brasil. Não há como negar que existe uma mobilização social velada para que os negros não ocupem locais importantes de visibilidade, de destaque, de influência como é o caso da política. Assim, entende-se que quem deve ocupar esses locais são justamente as pessoas brancas.

Esquecem que nós negros, somos seres políticos. E que a política feita por mulheres negras vem de longe. Fazemos política desde quando tráfico de escravos trazia os negros para cá. A sobrevivência e a resistência foram ações políticas e se os passos são lentos, isso tem a ver com a falta de acesso à educação, que sempre foi negado ao povo preto.

Sem educação, aparece a questão da autoestima. Um povo a quem se nega a própria história, sendo diminuído, oprimido e injustiçado, não aprendeu a brigar pelos espaços de poder. Sempre 
tinha um branco falando em nome de quem vive a realidade - marcada na pele - da desigualdade e da injustiça. Os negros, sistematicamente desumanizados, foram silenciados. Não pode ser mais dessa forma.

As mulheres negras, como eu, que estão ocupando espaços de poder, sabem da responsabilidade de desconstruir essa estrutura em que o homem branco sempre está no topo. E de trazer consigo a força ancestral de todas as mulheres negras, elaborando políticas públicas que garantam os nossos corpos ocupando todos os espaços. O futuro, não tenha dúvidas, é uma mulher negra que se move lentamente, mas chega onde quer. E não chega sozinha. 